УДК 37.014.3+378.6:37

DOI: https://doi.org/10.33989/2075-146x.2019.23.183183

\title{
ВАЛЕНТИНА ГРИНЬОВА
}

Полтавський національний педагогічний університет імені В. Г. Короленка

\section{ОРГАНІЗАЦІЯ ОСВІТНЬОГО СЕРЕДОВИЩА В ПЕДАГОГІЧНОМУ УНІВЕРСИТЕТІ ДЛЯ РЕАЛІЗАЦІЇ РЕФОРМИ «НОВА УКРАЇНСЬКА ШКОЛА»}

\begin{abstract}
У статті розглядається поняття освітнього середовища як сукупності умов, що впливають на розвиток $і$ формування здібностей, потреб, інтересів, свідомості майбутнього вчителя; воно являє собою комплекс матеріальних чинників, міжособистісних відносин суб'єктів освіти, спеціально організованих психологопедагогічних умов формування особистості. Емоційно сприятливий стан освітнього середовища визначається сформованістю індивідуального інтелектуального рівня, орієнтований на академічну підготовку, організацію життедіяльності, стимулювання особистісного розвитку студента. Стан емоційно сприятливого середовища визначається культурними цінностями закладу, його традиціями, позитивним іміджем.
\end{abstract}

Ключові слова: майбутні вчителі; студент; викладач; освітне середовище; майбутній учитель; педагогічна творчість; навчально-виховний процес; професіоналізм; емоційно сприятливе середовище

Постановка проблеми. Закон України про освіту (2016р.) регламентує підготовку педагогічних кадрів як провідне завдання модернізації вищої освіти. Тенденції розвитку освітньої системи в реалізації реформи «Нова Українська школа» спричинили появу системи вимог до професійних та особистісних якостей майбутніх учителів, спонукали до модернізації їхньої професійної підготовки, переорієнтації педагогічної освіти на формування фахівця нової генерації, здатного творчо вирішувати професійні функції в новій українській школі.

Підвищення рівня професіоналізму викладача, розвиток його здатності до інноваційної діяльності зумовлюють зосередження на професійній компетентності особистості, іiі наукових уміннях, інтересах, розвитку індивідуальності та творчих здібностей майбутніх учителів, створення для кожного студента психологічного комфорту, формування позитивного ставлення до освітнього середовища (Кремень, 2019).

Аналіз досліджень та публікацій. Удосконалення професійної підготовки майбутніх учителів в умовах сучасного закладу вищої освіти стосується насамперед способів підвищення ефективності освітнього процесу та ії змістового аспекту. Поза увагою викладачів часто залишаються проблеми міжособистісних взаємин у системі «викладач - студент» в освітньому середовищі університету.

Аналіз наукової літератури дозволяє говорити про те, що методологія середовищного підходу розкрита в дослідженнях Ю. Мануйлова, В. Серікова; емоційно-предметне середовище, його значення і оцінка розглядаються в працях І. Феттера, А. Куракіна; емоційно-почуттєву сферу як основу розвитку творчого мислення досліджує Л. Чеботарь; засоби активізації емоційної сфери студентів розкриває М. Татарінова.

Емоційно-позитивний настрій викладача і студента $є$ необхідним засобом психологічної комфортності всіх учасників освітнього процесу, який включає емпатійність, співпереживання, розуміння емоційного стану іншого у формі співчуття, створює сприятливі міжособистісні взаємини, забезпечує можливість спілкуватися. Сьогодні набуває актуальності підготовка майбутніх учителів до креативної професійної діяльності, формування їхної готовності до створення оптимальних умов для особистісного зростання (Ю. Бабанський, Г. Балл, М. Гриньова, Н. Гузій, А. Кузьмінський, О. Савченко). Проблема формування особистості майбутнього вчителя досліджена досить докладно: окреслені шляхи підвищення його професійної спрямованості, виокремлені умови формування професійно значущих якостей (І. Зязюн, О. Пєхота, О. Отич, Л. Хомич). Учені проаналізували психологічну, мотиваційну, морально-психологічну, професійну готовність майбутніх учителів до провадження професійної діяльності, що $є$ важливою характеристикою професіоналізму сучасного вчителя (Є. Барбіна, Т. Воронова, А. Деркач, О. Біда, Н. Бідюк, Е. Карпова, В. Моляко, О. Мороз).

Закономірності та принципи професійного становлення особистості майбутнього вчителя на засадах педагогічної майстерності, шляхи і методи підготовки майбутніх вчителів розкриті в роботах І. Зязюна, Н. Гузій, В. Стрельнікова, П. Сауха. Проблемі формування освітнього середовища як чинника творчого розвитку особистості майбутнього вчителя присвячені роботи Є. Бондаревської, О. Гукаленко, І. Беха, І. Жерносека, О. Козлової.

Важливим засобом підготовки майбутнього вчителя визнано створення освітніх умов для всебічного розвитку його можливостей і здібностей. При цьому важливим є підвищення наукового, освітнього впливу професорськовикладацького складу на професійне становлення майбутніх учителів за такими пріорітетними напрямками: впровадження інновайційних моделей особистісно орієнтованої освіти, формування позитивної мотивації навчальної діяльності, долучення до активної навчальної діяльності; надання психолого-педагогічної допомоги у стимулюванні самостійного навчання студентів, застосування матеріально-технічного обладнання в емоційно спрямованому освітньому середовищі.

Мета статті полягає в обгрунтуванні шляхів створення емоційного освітнього середовища для особистісного і професійного розвитку майбутнього вчителя. 
Виклад основного матеріалу. Освітнє середовище - це поєднання умов, що впливають на розвиток і формування здібностей, потреб, інтересів, свідомості особистості майбутнього вчителя для взаємодії 3 навколишнім світом. Взаємодія викладача, студента і освітнього середовища в навчальній діяльності неможлива без урахування особливостей усіх суб'єктів освітнього процесу.

Освітнє середовище - це простір, у якому відбувається взаємодія викладача і студента, атмосфера, що включає, дух, комфортність, до яких залучено кожного учасника освітнього процесу, та сукупність психологічного, соціального i просторово-предметного матеріального факторів. При цьому, всі фактори взаємопов'язані, доповнюють, збагачують один одного і впливають на кожного суб'єкта освітнього середовища.

Освітнє середовище являє собою сукупність матеріальних чинників, міжособистісних відносин суб'єктів освіти і спеціально організованих психолого-педагогічних умов формування особистості. Освітнє середовище має місце там, де відбувається комунікативна взаємодія суб'єктів, де кожен з учасників виявляється здатним змінити власну позицію і створити новий проект діяльності на основі цього досвіду. Університетьське середовище- це внутрішній простір університету, сукупність умов існування і розвитку студентів і викладачів, що визначається успішністю соціально-психологічної адаптації студентів, їхнім розвитком у процесі життєдіяльності. Вплив викладачів на якість освіти і психічне здоров'я студентів створює комфортне внутрішнє емоційно сприятливе середовище університету.

Аналіз суджень викладачів Полтавського національного педагогічного університету імені В. Г. Короленка змушує зробити висновок, що рівень їхньої готовності до створення емоційно сприятливого середовища для майбутніх вчителів залишає бажати кращого, а саме: 33\% викладачів відчувають труднощі при вирішенні різних проблем у освітньому процесі, 12 \% не готові до здійснення індивідуального підходу до студентів, 11\% не використовують інформаційні технології,16 \% не застосовують раціональних методів спілкування в педагогічних ситуаціях, $28 \%$ не готові до створення для студентів емоційно сприятливого освітнього середовища.

Емоційно сприятливе середовище є одним із вирішальних факторів у розвитку особистості студента, а самі студенти своїми діями і вчинками активізують елементи середовища і тим самим створюють його для себе. Середовище як постійне джерело поповнення особистого досвіду, знань $є$ тим об'єктивним чинником, що визначає поведінку, процес самовизначення і самореалізації кожного студента. Емоційно сприятливе середовище для студентів - це сукупність соціально-педагогічних умов, що забезпечують емоційно-позитивний настрій, психологічний комфорт, педагогічну взаємодію, співпрацю і співтворчість у системі «студент - викладач», свободу вибору дій та ситуацій успіху в досягненні цілей (Гузій, 2004).

Емоційно сприятливе середовище - це феномен, що володіє комплексом певних позитивних психологічних характеристик, які впливають на особистість студента та викладача. При цьому, на формування індивідуальнопсихологічних і особистісних особливостей студентів впливають такі фактори: просторово-предметне, соціальне оточення, соціокультурна обстановка, матеріально-технічне забезпечення освітнього процесу, які створюють сприятливе середовище з певними характеристиками і різними розвивальними можливостями. Загалом, емоційно сприятливе середовище - це стан освітнього середовища, яке сприяє повноцінному та гармонійному розвитку особистості.

Як свідчить педагогічна практика, 83 \% першокурсників, вступаючи до закладу вищої освіти, відчувають нестійкий, дискомфортний стан в освітньому середовищі університету, що ускладнює виконання освітніх вимог професорсько-викладацького колективу, 73\% відчувають утруднення в спілкуванні з викладачами, студентським колективом, що актуалізує комфортність освітнього середовища як важливий показник емоційно сприятливого середовища. Комфортне середовище у вищому закладі освіти - це комплекс позитивних, емоційних взаємин, що створюють інтелектуально-емоційний фон, впливають на актуалізацію творчого потенціалу, творчої діяльності, знижують несприятливу дію шкідливих факторів. На характер емоційно сприятливого середовища впливає наступне: сукупність педагогічних технологій, що застосовується, засоби організації навчально-виховного процесу і розвитку взаємин у системі «викладач-студент».

Матеріально-технічна база освітнього процесу $\epsilon$ частиною просторово-предметного змісту середовища університету. Інтегративним критерієм його є здатність забезпечити всім суб'єктам достатньо можливостей для емоційно сприятливого особистісного розвитку. Емоційна комунікативність викладача проявляється у спрямованості, його готовності до співпраці, володінням технікою спілкування (вербальної і невербальної), здатності зрозуміти точку зору студента і прийняти іiі, у витримці, такті, правильній, емоційній мові, контролі емоційного стану (Зязюн (Ред.), 1997).

Емоційно сприятливий стан освітнього середовища виявляється в кожному окремому випадку через сформованість індивідуального інтелектуального рівня, оскільки орієнтований на академічну підготовку, організацію життєдіяльності, стимулювання особистісного розвитку студента. Стан емоційно сприятливого середовища визначається культурними цінностями закладу, його традиціями, позитивним іміджем.

Для розвитку емоційно сприятливого освітнього середовища для підготовки майбутніх учителів на природничому факультеті Полтавського національного педагогічного університету імені В. Г. Короленка функціонує навчальна лабораторія - ботанічний сад, який розташований на рельєфній території східної частини міста Полтави. Сад містить кілька відділів: дендрарій, відділ квітково-декоративних рослин, музей українського квітникарства під відкритим небом, зелений клас, альпійську гірку, відділ сільськогосподарських та лікарських культур, плодовий сад. Дендрарій розміщений на південному схилі ботанічного саду на площі майже 1,8 га. Він складається 3 ділянки парку, де в основу розміщення порід покладено ландшафтно-пейзажний принцип. Колекція дерев та чагарників налічує 136 видів.

Помітне місце в експозиції саду посідає Музей українського національного декоративного квітникарства під відкритим небом. Тут зростають дуб звичайний, що символізує довголіття та міцність, береза бородавчаста оберег господаря і родини, верба ламка - символ повноти життя, довголіття і жіночої краси. Під скляним дахом 
оранжереї водночас розмістилися «полтавські» тропіки, субтропіки та пустеля. Колекція флори засушливих районів Землі представлена рослинністю Африки та Південної Америки. Численні кактуси з яскравими плодами та юкки серед кам'яних брил імітують пустелю, агави викликають зацікавленість зовнішнім виглядом і біологічними властивостями. Не менш цікавою є група рослин - представників субтропіків: рожево-білі олеандри, мирти, гібіскуси, цифомандри.

Колекція тропіків широко представлена мешканцями дощових лісів - фікусами, велетенськими ліанами. Над міні-басейном розкинулися зарості циртоміуму дворядного та гігантської ліани монстери делікатесної. Добре акліматизувалася в оранжереї і драцена, або драконове дерево, представлене декількома видами. Над усім цим здіймаються велетенські пальми заввишки до10 метрів, фінікові пальми 3 плодами і віяльні - ерітея, сабаль, трахікарпус із ароматними суцвіттями. Колекція рослин ботанічного саду постійно поповнюється новими видами.

Розглянемо сучасні кімнати-музеї природничого факультету, які відкриті за ініціативою декана природничого факультету, доктора педагогічних наук, професора М.В. Гриньової протягом 1995-2019 років.

Перші експозиції музею еволюційної зоології створені в 1957 році викладачем кафедри зоології Миколою Івановичем Гавриленком. У подальшому активну участь у створенні музейних експозицій брали викладачі кафедри зоології І. Д. Іваненко, М. І. Петрик, Б. Р. Пилявський, В. М. Закалюжний, О. Г. Сердюк, О. М. Руденко, М. В. Слюсар, С. А. Новописьменний. Музейні експозиції розміщені в навчальних аудиторіях №№ 30-31 та в холі першого поверху корпусу №1 ПДПУ імені В.Г. Короленка і включають розділи: «Найпростіші», «Губки», «Кишковопорожнинні», «Черви», «Молюски», «Членистоногі», «Птахи», «Ссавці». Експозиції музею активно використовуються в навчально-науковій та екскурсійній діяльності.

Музей палеозоології хребетних тварин відкритий у 2004 році за активної участі викладачів кафедри біології людини і тварин О. Г. Сердюка, В. М. Закалюжного, С. А. Новописьменного. Експонати музею включають фосілії різних форм збереження так званої «мамонтової» фауни, зібрані впродовж 50 років на території Полтавщини. Серед експонатів - викопні залишки мамонта, волохатого носорога, первісного бізона, гіпаріона, гігантського оленя, північного оленя. У музеї демонструється динамічна модель динозавра мезозойської ери - тиранозавра рекса, сконструйована В. М. Галичем та О. М. Руденком. Експозиція музею доповнена репродукціями картин, виконаними полтавським художником В. І. Отіськом.

Експозиції музею загальної $\boldsymbol{i}$ регіональної геології відкриті в 2003 році до 140-літнього ювілею академіка, геолога В. І. Вернадського. Музейні експозиції створені за активної участі завідувача кафедри біології людини і тварин, кандидата геолого-мінералогічних наук В. М. Закалюжного, геолога-науковця, кандидата геологомінералогічних наук В. О. Кривошеї та студентів природничого факультету. Тут демонструється понад 120 видів мінералів і гірських порід, колекція видів мінеральних вод України і світу. Експозицією ілюструються приклади практичного використання мінералів і гірських порід у різних галузях народного господарства. Її складники активно використовуються в навчально-науковій та екскурсійній діяльності. Як частина освітнього середовища 3ВО, музеї є складниками його соціально-культурного простору, зоною інтеграції освітніх систем, їхніх окремих елементів

Висновки. Середовище вищого закладу освіти - це сформований простір, що забезпечує можливість для розвитку особистості, і засіб адаптації особистості майбутнього вчителя. Емоційно сприятливе середовище університету характеризується емпатійністю студента, сприятливим психологічним кліматом, матеріальнотехнічною базою, що забезпечує високий ступінь емоційної включеності викладачів і майбутніх вчителів до освітнього процесу. Характеристиками емоційно сприятливого середовища в університеті є екологічність взаємин у системі «викладач - студент» на основі оптимізму, життєрадісності, взаємоприйнятних стосунків, що будуються на принципах взаємодопомоги, співпраці, заохочення самостійності, активності та ініціативи, підвищений ступінь, мотивації студентів - як можливості досягнення успіху.

Основними показниками та критеріями емоційно сприятливого емоційного середовища університету $є$ емоційно-позитивний настрій; емпатійність; мобільність; задоволеність вибором майбутньої професії; емоційнопочуттєва єдність; екологічність взаємовідносин. Створення сприятливого психоемоційного клімату в освітньому середовищі є важливою складовою педагогічної роботи, оскільки психологічно здорові, творчі, впевнені у своїх силах майбутні вчителі являють собою особливу цінність для реалізації освітньої реформи «Нова Українська школа».

\section{Список використаних джерел}

Гузій, Н. В. (2004). Основи педагогіки професіоналізму: навч. посіб. Київ: НПУ ім. М. П. Драгоманова.

Зязюн, І. А. (Ред.). (1997). Педагогічна майстерність: підручник.Київ: Вища шк.

Кремень, В. Г. (2019). Проблема якості української освіти. В кн. М. В. Гриньова (Ред.), Методика навчання природничих дисциплін у середній та вищій школі: матеріали Міжнар. наук.-практ. конф. (С. 5-7). Полтава: ТОВ «Сімон».

\section{References}

Huzii, N. V. (2004). Osnovy pedahohiky profesionalizmu [Fundamentals of pedagogy of professionalism]: navch. posib. Kyiv: NPU im. M. P. Drahomanova [in Ukrainian]. 
Kremen, V. H. (2019). Problema yakosti ukrainskoi osvity [The problem of the quality of Ukrainian education]. In M. V. Hrynova (Ed.), Metodyka navchannia pryrodnychykh dystsyplin u serednii ta vyshchii shkoli [Methods of teaching natural sciences in secondary and high school]: materialy Mizhnar. nauk.-prakt. konf. (pp. 5-7). Poltava: TOV «Simon» [in Ukrainian].

Ziaziun, I. A. (Red.). (1997). Pedahohichna maisternist [Pedagogical skills]: pidruchnyk.Kyiv: Vyshcha shk [in Ukrainian]

\title{
GRYNOVA V.
}

Poltava V. G. Korolenko national pedagogical University, Ukraine

\section{ORGANIZATION OF EDUCATIONAL ENVIRONMENT AT THE PEDAGOGICAL UNIVERSITY FOR THE IMPLEMENTATION OF THE NEW UKRAINIAN SCHOOL REFORM}

The article deals with the concept of the educational environment - a set of conditions that affect the development and formation of abilities, needs, interests, consciousness of the future teacher is a set of material factors, interpersonal relations of subjects of education and specially organized psychological and pedagogical conditions of personality formation. Emotionally favorable state of the educational environment is determined by the formation of individual intellectual level, focused on academic preparation, organization of life, stimulation of student's personal development. The state of an emotionally favorable environment is determined by cultural values, institution, its traditions, positive image./

The main indicators and criteria of the emotionally favorable emotional environment of the university are the emotionalpositive mood; empathy; mobility; satisfaction with the choice of future profession, emotional and sensual unity; environmental friendliness. Creating a favorable climate in an emotionally-supportive educational environment is an important component of pedagogical work, as psychologically healthy, creative, confident future teachers are of particular value for the implementation of the educational reform of the New Ukrainian School.

Keywords: future teachers; student; teacher; education; student collective; pedagogical creativity; educational process; professionalism; environment; emotionally favorab leenvironment.

УДК 37.091.113.014.3

DOI: https://doi.org/10.33989/2075-146x.2019.23.183186

МАРИНА ГРИНЬОВА

ORCID ID 0000-0003-3912-9023

ОЛЕНА ЖДАНОВА-НЕДІЛЬКО

ORCID ID 0000-0002-1414-2355

Полтавський національний педагогічний університет імені В.Г. Короленка

\section{ПІДГОТОВКА КЕРІВНИКА НОВОЇ УКРАЇНСЬКОЇ ШКОЛИ ДО ПАРТНЕРСЬКОЇ ВЗАЕМОДІЇ З СУБ'ЄКТАМИ ОСВІТНЬОГО СЕРЕДОВИЩА}

\begin{abstract}
У статті розглядаються проблеми, що пов'язані з кількома важливими аспектами педагогічної інноватики в сучасній Україні. Аналізуються вимоги до керівника Нової української школи як інтегруючої постаті в контексті освітнього середовища, організація його стосунків з учнями, педагогами, батьками школярів, представниками місцевих громад. Обговорюється специфіка партнерської взаємодії як засобу встановлення конструктивних контактів між суб'єктами, зацікавленими в успішному освітньому результаті. 3'ясовуються можливості вищої школи щодо формування у майбутнього освітнього менеджера здатності до зазначеної взаємодії.
\end{abstract}

Ключові слова: Нова украӥнська школа; керівник; освітнє середовище; територіальна громада; батьківська громадськість; партнерська взаємодія; вища школа; професійна підготовка; квазіпрофесійна діяльність

Постановка проблеми. У поступі сучасного суспільства за актуальними векторами його гуманітарного розвитку спостерігається чимало проблем, успішне вирішення яких можливе лише 3 огляду на особистість управлінця, його теоретичну обізнаність і практичну готовність до діяльності, здатність конструктивно узгоджувати загальне і конкретне, наявне і потенційне, об'єктивне і суб'єктивне, володіти технологіями організації освіти і самоорганізації управлінської діяльності в її контексті. Адже, як зазначає український соціолог Л. Бевзенко, «соціокультурні процеси мають свою внутрішню активність, свої варіанти можливого-неможливого. I лише спираючись на обмежені цими варіантами рамки нашої свободи і суб'єктності, ми можемо вибудовувати свої прогнози і проекти майбутнього - власні, групові, суспільні» (Бевзенко, 2018, с. 103).

Реалізація Концепції Нової української школи як одного з базових освітньо-реформаційних проектів останніх років визначає шлях до вирішення проблеми формування суспільства майбутнього саме через окреслене вище поєднання - індивідуального, колективного, суспільного. Тож постає проблема наявності у освітньому процесі потужного об’єднувального і спрямовувального начала, що, спираючись на сучасну теорію менеджменту і вміло 